\title{
TOAD-64, a Gene Expressed Early in Neuronal Differentiation in the Rat, Is Related to unc-33, a C. elegans Gene Involved in Axon Outgrowth
}

\author{
Jane E. Minturn, Hugh J. L. Fryer, Daniel H. Geschwind, a and Susan Hockfield \\ Section of Neurobiology, Yale University School of Medicine, New Haven, Connecticut 06510
}

\begin{abstract}
Using two-dimensional gel electrophoresis we previously identified membrane-associated proteins that are upregulated over the course of neurogenesis. One of these, TOAD-64 (Turned On After Division, $64 \mathrm{kDa}$ ), is expressed immediately after neuronal birth and is dramatically downregulated in the adult. The gene encoding TOAD-64 has now been cloned, and its sequence shows homology to the unc-33 gene from $C$. elegans, mutations in which lead to aberrations in axon outgrowth. Northern and in situ hybridization show that TOAD-64 mRNA Is enrlched In the nervous system and is developmentally regulated in parallel with the protein. The expression of the TOAD-64 protein and gene coincident with initial neuronal differentiation and the downregulation when the majority of axon growth is complete suggests a role in axon elaboration. Three additional lines of evidence support this possibility: TOAD-64 is upregulated following neuronal induction of P19 and PC12 cells; the protein is found in lamellipodia and filopodia of growth cones; and axotomy of the sciatic nerve induces reexpression. While the sequence of TOAD-64 lacks a signal sequence and therefore is likely to encode a cytoplasmic protein, biochemical experiments demonstrate that the protein is tightly, but noncovalently, associated with membranes. The data presented here suggest that TOAD-64 could be a central element in the machinery underlying axonal outgrowth and pathfinding, perhaps playing a role in the signal transduction processes that permit growing axons to choose correct routes and targets.

[Key words: growth cone, axonogenesis, membrane protein, axon outgrowth, regeneration, unc-33, differentiation, axon, development]
\end{abstract}

As the brain develops, a population of mitotically active progenitor cells gives rise to postmitotic cells that assume the propcrtics of ncurons or glia. Postmitotic neurons elaborate processes that are involved in the migration of neurons to their adult po-

\footnotetext{
April 19, 1995; revised June 7, 1995; accepted June 12, 1995.

This work was supported by NIH NS22807 (S.H.). J.E.M. is a Howard Hughes Medical Institute Predoctoral Fellow. We thank Gail M. Kelly for expert assistance in the histological studies, Hong Zhang for her work on the primary neuronal cultures, Jim Boulter for generously sharing cDNA libraries, Anthony Frankfurter for providing antibody to class lll $\beta$-tubulin, and members of the Hockfield lab for critically reading the manuscript.

Correspondence should be addressed to Susan Hockfield, Section of Neurobiology, Yale University School of Medicine, 333 Cedar Street, New Haven, CT 06510 .

aPresent address: Department of Neurology, UCLA School of Medicine, 710 Westwood Plaza, Los Angeles, CA 90024.

Copyright (C) 1995 Society for Neuroscience $0270-6474 / 95 / 156757-10 \$ 05.00 / 0$
}

sitions as well as the elaboration of axonal and dendritic arbors. To identify proteins that participate in early functions of developing neurons, we previously used two-dimensional gel electrophoresis to compare membrane associated proteins expressed by progenitor cells to those expressed by postmitotic neurons (Geschwind and Hockfield, 1989). We compared membrane preparations from the rat neocortex at embryonic day 14 (E14), when the neocortex contains largely progenitor cells, to membrane preparations from the cortex at E21, when the neocortex contains the mature complement of neurons. Ten proteins that are upregulated greater than threefold between E14 and E20 were identified. One of these, TOAD-64 (Turned On After Division, $64 \mathrm{kDa}$, initially labeled protein 310 ) was selected for further study. By two-dimensional gel analysis, TOAD-64 was upregulated sevenfold between E14 and E21, appeared to be enriched in brain, and represented approximately $0.1 \%$ of total protein at E21.

Antisera raised to synthetic peptides based on amino acid sequence of TOAD-64 permittcd a morc detailcd analysis of the regulation and distribution of TOAD-64 (Minturn et al., 1995). As predicted from the original design of the two-dimensional gel study, TOAD-64 is expressed by neurons and not by progenitor cells. It is among the earliest known proteins expressed by postmitotic neurons. The protein is dramatically downregulated during the second postnatal week to an almost undetectable level in the adult. The neural specificity and timing of expression suggested that TOAD-64 might play a role in axonogenesis or neuronal migration.

Here we report the full length sequence of a cDNA encoding TOAD-64 and show the pattern of expression of its mRNA, in situ and in two cell lines. TOAD-64 is homologous to the $C$. elegans unc-33 gene, mutations in which lead to aberrant patterns of axon outgrowth (Hedgecock et al., 1985; Li et al., 1992). Consistent with a role in axon outgrowth in the mammalian nervous system, the TO $\Lambda \mathrm{D}-64$ gene is expressed early in neuronal differentiation and is downregulated in the adult. It is reexpressed in the adult during sciatic nerve regeneration. These data, together with the regulation of expression in parallel with the neuritogenesis in PC12 and P19 cells, and the localization of the TOAD-64 protein to growth cones, indicate that TOAD-64 may be a component of the intracellular machinery by which growing neurons elaborate axons.

\section{Materials and Methods}

PCR amplification. Degenerate DNA oligomer primers were designed based on peptide sequences obtained from microsequencing of purified TOAD-64 protein. The only primer combination that resulted in a single major PCR product was 5'-GA(C/T)(C/T)TIGT(G/T/C)AT(A/C/T)TG 
GGA(C/T)CC-3' (72-fold degenerate, $5^{\prime}$ primer) and $5^{\prime}$-GTC(G/A)AAIACIGG(A/C/G/T)C C(G/A)TC(G/A)TA-3' (32-fold degenerate, 3' primer). First strand cDNA, prepared using polyA RNA isolated from postnatal day 5 (P5) rat cortex and random primers, was used as a template for PCR. The PCR conditions were as follows: $94^{\circ} \mathrm{C}, 1 \mathrm{~min} ; 49^{\circ} \mathrm{C}, 2$ min; $72^{\circ} \mathrm{C}, 2 \mathrm{~min}$; for 35 cycles. PCR products were analyzed by agarose gel electrophoresis, and a major band [280 base pair (bp)] was isolated and cloned into the TA cloning vector pCRII (Invitrogen). The insert was sequenced using the vector M13 and T7 primer sites.

Isolation of cDNA clones. An embryonic day 18 (E18) rat brain library (generously provided by J. Boulter, The Salk Institute) in the vector lambda $\mathrm{ZAP}$ was plated on $E$. coli (strain BB4) at a density of 40,000 phage per $150 \mathrm{~mm}$ plate, and 400,000 clones screened according to standard techniques (Sambrook et al., 1989). Briefly, nitrocellulose filters were prehybridized at $65^{\circ} \mathrm{C}$ for $4-5 \mathrm{hr}$ in $6 \times \mathrm{SSC}(1 \times=0.15$ M sodium chloride, 0.015 M sodium citrate), $0.1 \%$ SDS, $1 \times$ Denhardt's (0.02\% Ficoll, $0.02 \%$ BSA, $0.02 \%$ polyvinylpyrrolidone), and $100 \mu \mathrm{g} /$ $\mathrm{ml}$ salmon sperm DNA. Hybridization was carried out in the same solution with the addition of $5 \times 10^{5} \mathrm{cpm} / \mathrm{ml}$ of radiolabeled probe at $65^{\circ} \mathrm{C}$ for $20 \mathrm{hr}$. Filters were washed once in $2 \times$ SSC, $0.1 \%$ SDS, and twice in $0.2 \times \mathrm{SSC}, 0.1 \% \mathrm{SDS}$, at $65^{\circ} \mathrm{C}$ for $20 \mathrm{~min}$. For the initial screening, filters were probed with the $280 \mathrm{bp}$ PCR product radiolabeled ([32P]-dCTP, Amersham) by random priming (Feinberg and Vogelstein, 1983) (NEBlot Kit, New England Biolabs, Inc.). To obtain the $5^{\prime}$ end of the gene, an additional 200,000 clones were screened with a $230 \mathrm{bp}$ region amplified from the 5 '-most end of the initial clones.

DNA sequencing and analysis. DNA sequence was obtained by the dideoxy chain termination method using the Sequenase kit (Sanger et al., 1977) (United States Biochemical Corp.). Bluescript SK/T7 primers or CDNA specific 20-mers were used. Sequence was verified from overlapping clones or by sequencing both strands of DNA. Sequence compressions were resolved using dITP nucleotides and terminal deoxynucleotidyl transferase in the sequence reaction mix. Sequence alignments and analyses were performed using the University of Wisconsin Genetics Computer Group (GCG) software

Northern analysis. Total RNA $(25 \mu \mathrm{g})$ was denatured in $2.2 \mathrm{M}$ formaldehyde, $50 \%$ formamide, $1 \times$ MOPS (3-(N-morpholino) propanesulfonic acid) buffer at $65^{\circ} \mathrm{C}$ for $15 \mathrm{~min}$. The RNA was electrophoresed on a $1.0 \%$ agarose-formaldehyde gel with $1 \times$ MOPS buffer at $50 \mathrm{~V}$ with buffer recirculation, and blotted to Zetaprobe (BioRad). Blots were prehybridized at $65^{\circ} \mathrm{C}$ for $30 \mathrm{~min}$ in $7 \%$ SDS, $1 \%$ BSA, $0.5 \mathrm{M}$ phosphate buffer (pH 6.8) (PB), and $1 \mathrm{mM}$ EDTA. Hybridization was carried out overnight in the same buffer containing $1-5 \times 10^{6} \mathrm{cpm} / \mathrm{ml}\left[{ }^{32} \mathrm{P}\right] \mathrm{dCTP}-$ labeled cDNA. Blots were washed twice in 5\% SDS, $0.5 \%$ BSA, 40 mM PB, 1 mM EDTA, and once in $1 \%$ SDS, $40 \mathrm{~mm}$ PB, 1 mM EDTA at $65^{\circ} \mathrm{C}$ for $20 \mathrm{~min}$ (Church and Gilbert, 1984) and exposed to film (Hyperfilm, Amersham) at $-70^{\circ} \mathrm{C}$. The ubiquitously expressed, nondevelopmentally regulated gene cyclophilin (Lenoir et al., 1986; Danielson, 1988) was used to determine equal loading of lanes.

In situ hybridization. In situ hybridization was carried out as described by Jaworski et al. (1994). Briefly, 12-14 $\mu \mathrm{m}$ thick fresh-frozen sections were thaw mounted onto gelatin-coated slides and postfixed in $0.1 \mathrm{M}$ phosphate-buffered $4 \%$ paraformaldehyde. Sections were probed with $\left.{ }^{[5} \mathrm{S}\right] \mathrm{CTP}$ (New England Nuclear)-labeled antisense or sense cRNA transcribed in vitro from a 280 bp PCR product inserted into the vector pCRII (Invitrogen). Following hybridization and washing, initial localization of probe was determined by exposing the slides to film (Hyperfilm, Amersham) for $48 \mathrm{hr}$. Autoradiograms were used as negatives for prints. For higher resolution, the slides were exposed to Kodak NTB-2 liquid emulsion, developed after 2-5 d, and counterstained with cresyl violet. An antisense probe for the gene for the middle subunit of neurofilament (NF) (Martin et al., 1992) was used as a positive control.

Immunohistochemistry. Sprague-Dawley rats (Charles River Laboratory) ages E17 to adult were perfused transcardially with $0.1 \mathrm{M}$ sodium phosphate ( $\mathrm{pH} 7.4)(\mathrm{PB})$, then $4 \%$ paraformaldehyde (PFA) in $\mathrm{PB}$. Whole brains or spinal cords were dissected out and postfixed in $4 \%$ PFA for $24 \mathrm{hr}$ at $4^{\circ} \mathrm{C}$, then equilibrated in $30 \%$ sucrose in PB. Coronal sections of $\mathrm{E} 17$ brain were cut at $30 \mu \mathrm{m}$, and transverse sections of adult spinal cord cut at $50 \mu \mathrm{m}$ on a cryostat and collected as free-floating sections in PB for immunohistochemistry. Tissue sections were incubated in rabbit anti-TOAD-64 (1:2000) (Minturn et al., 1995) at room temperature over night. The secondary antibody was HRPconjugated goat anti-rabbit IgG (1:200, Cappel). HRP was localized using a $0.7 \mathrm{mg} / \mathrm{ml}$ solution of $3,3^{\prime}$-diaminobenzidine tctrahydrochloridc (DAB) with $0.003 \% \mathrm{H}_{2} \mathrm{O}_{2}$ in PB. Sections were dehydrated in graded ethanols, equilibrated in xylenes, and coverslipped with Permount (Fisher Scientific). Sections retrogradely labeled with Fast blue were mounted in Aqua-Poly Mount (Polysciences, Inc.)

Cell culture. Culture and induction of P19 cells was as previously described (McBurney et al., 1988). P19 cells (ATCC) were maintained in alpha modified MEM supplemented with $2.5 \%$ FCS and $7.5 \%$ newborn calf serum in $100 \mathrm{~mm}$ tissue culture plates. Cells adhering to the plates were treated with $0.05 \%$ trypsin $/ 0.5 \mathrm{mM}$ EDTA in Dulbecco's phosphate-buffered saline (DPBS; GIBCO/BRL) without $\mathrm{Ca}^{2+}$ or $\mathrm{Mg}^{2+}$, triturated with a flame constricted pipette in complete medium, and plated into bacteriological culture dishes at a density of $1 \times 10^{5}$ cell $/$ ml. For neural induction the culture medium was supplemented with 1 $\mu \mathrm{M}$ all trans-retinoic acid (day 0 ). Four days after induction the floating clumps of cells were treated with trypsin, dispersed by trituration, and plated onto culture dishes at a density of $5 \times 10^{4} \mathrm{cells} / \mathrm{cm}^{2}$ in medium lacking inducer. Cells were collected and RNA prepared (as described above) at $2,4,6,8$, and $11 \mathrm{~d}$ following induction or at 4 and $8 \mathrm{~d}$ without induction.

PC12 cells were plated on polyornithine/laminin treated $100 \mathrm{~mm}$ tissue culture dishes at a density of 75 cells $/ \mathrm{mm}^{2}$ in Dulbecco's Modified Eagle's Medium (DMEM; GIBCO/BRL)/10\% FCS. Twenty-four hours after plating the medium was replaced with medium containing $100 \mathrm{ng} /$ ml NGF. Cells were harvested for either RNA or protein before NGF induction and at $1,3,5$, and $7 \mathrm{~d}$ following induction.

Primary neuronal cultures were made of rat sensory ganglia. Dorsal root ganglia (DRG) dissected from E16 Sprague-Dawley rat embryos in DPBS, were collected in DMEM. Following washes in $\mathrm{Ca} / \mathrm{Mg}$-free DPBS, ganglia were treated with $0.05 \%$ trypsin in $\mathrm{Ca} / \mathrm{Mg}$-free DPBS for 30 min at $37^{\circ} \mathrm{C}$. After washes in DMEM supplemented with $10 \%$ fetal calf serum (Hyclone), $2 \mathrm{~mm}$ glutamine and penicillin-streptomycin, cells were dissociated by trituration using a fire-polished Pasteur pipette. Cells were plated onto flame sterilized, polyornithine/laminin (Sigma) coated, round cover glasses, at a density of 90 cells $/ \mathrm{mm}^{2}$ in medium supplemented with $50 \mathrm{ng} / \mathrm{ml} 2.5 \mathrm{~S}$ NGF (Collaborative Research). After $20 \mathrm{hr}$ at $37^{\circ} \mathrm{C}$ and $5 \% \mathrm{CO}, 4 \%$ phosphate-buffered paraformaldehyde/ $0.2 \%$ glutaraldehyde was added to the cultures in a volume equal to that of the culture medium. After 10 min the cells were washed extensively with $0.1 \mathrm{M}$ phosphate buffer. Cultures were incubated for 2 lir with DMEM supplemented with $5 \%$ fetal calf medium, $0.1 \%$ glycine, $0.1 \%$ lysine, and $0.2 \%$ Triton $\mathrm{X}-100$.

Immunohistochemistry was performed as described above, using either rabbit antisera to TOAD-64 or an antibody to class III $\beta$-tubulin (Lee et al., 1990a,b; Easter et al., 1993; Minturn et al., 1995), generously provided by Dr. Anthony Frankfurter, University of Virginia. Antibody binding was visualized with species specific antibodies and DAB with $2 \% \mathrm{NiSO}_{4}$ for HRP in single-labeling studies, or with FITC or Texas red for double-labeling studies.

Sciatic nerve lesion. Adult Sprague-Dawley rats weighing 150-200 g were anesthetizcd with $400 \mathrm{mg} / \mathrm{kg}$ chloral hydrate, and the right sciatic nerve was exposed at the level of the midshaft femur. The nerve was crushed with forceps and injected (proximal to the crush) with 1 $\mu l$ of the retrograde tracer Fast blue (1\% solution in PB). Survival times ranged from $4 \mathrm{hr}$ to 2 weeks after surgery, at which time the animals were deeply anesthetized and perfused transcardially with $0.1 \mathrm{M}$ PB followed by $4 \%$ paraformaldehyde in PB. The spinal cords were removed at the level of the lumbar enlargement and processed for immunohistochemistry as described above. The motor neurons of the anterior horn of the spinal cord labeled with Fast blue were visualized using epifluorescence microscopy with a UV filter.

Tissue extraction and Western analysis. Tissues from euthanized animals were dissected and used immediately or stored frozen at $-70^{\circ} \mathrm{C}$ Fresh or frozen tissues were homogenized in a Teflon-glass Potter-Elvehjem homogenizer at a concentration of $0.2 \mathrm{gm}$ (wet weight) of tissue $/ \mathrm{ml}$ of phosphate-buffered saline (PBS) $(50 \mathrm{~mm}$ sodium phosphate pH $7.4,150 \mathrm{~mm} \mathrm{NaCl}$ ) containing a cocktail of protease inhibitors (1 mM EDTA, $1 \mathrm{mM}$ phenylmethylsulfonyl fluoride, $5 \mathrm{~mm} \mathrm{~N}$-ethylmaleamide, $5 \mathrm{~mm} \epsilon$-amino-n-caproic acid, $5 \mu \mathrm{g} / \mathrm{ml}$ leupeptin, and $1 \mu \mathrm{g} / \mathrm{ml}$ pepstatin A). Whole homogenate samples were taken directly from this preparation. Supernatant $(S)$ and pellet $(P)$ fractions were prepared from the homogenates as follows. The samples were centrifuged at 100,000 $\times g$ for $1 \mathrm{hr}$ and the supernatant (S fraction) was saved. The resulting pellet was rehomogenized with PBS and again separated into pellet and supernatant fractions by centrifugation. For differential extractions this pellet (from the second centrifugation) was homogenized in either 0.1 $\mathrm{M} \mathrm{Na}_{2} \mathrm{CO}_{3}$ pH11, PBS, $2 \mathrm{M} \mathrm{NaCl}$ in PBS, 1\% Triton X-100 in PBS, 10 
gaggattgcatctgtctcttatagttttgaaatctcctaatagcaagaccagctaagggattgtacctttttcctacaaatataaatatatatatattttaaaccaagtctttttttccg 120 gctctctttgctttaaagctgtcctcttgaaattacttccccccgccecccggagagatgtettatcaggggaagaaaatattccacgcatcacgagcgatcgtcttctgatcaaaggt 240

ggcaagattgtgaatgatgaccagtccttctatgcagacatatacatggaagatgggttgatcaagcaaataggagaaaacetgattgtgccaggaggggtgaagaccatcgaagcccac 360

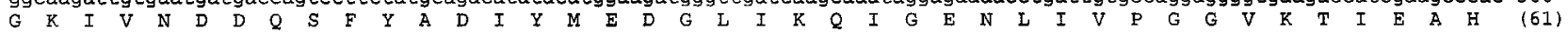

tccagaatggtgatccetggaggaattgacgtgcacactcgcttccagatgccagaccagggaatgacatcagctgatgacttcttccagggaaccaaggcagccetggccggaggaacc 480

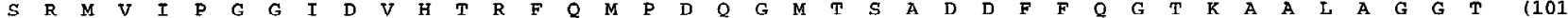
accatgatcatcgaccatgttgttcctgagcccgggacaagcctattggcagcctttgatcagtggagggagtgggcggacagcaagtcctgctgtgactattcgctgcacgtggacatc 600

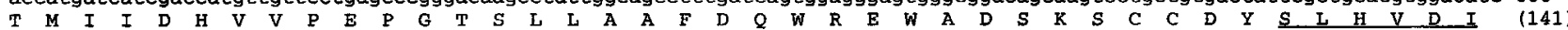
acggagtggcacaagggcatccaggaggagatggaagctctggtgaaggaccacggggtaaactccttcctcgtgtacatggctttcaaagatcggttccagctgacggattcccagatc 720 $\begin{array}{llllllllllllllllllllllllllllllllllllllllllll}T & E & W & H & K & G & I & Q & E & E & M & E & A & L & V & K & D & H & G & V & N & S & F & \text { I } & V & Y & M & A & F & K & D & R & F & Q & I & T & D & S & Q & I & (181)\end{array}$ tatgaagtactgagcgtgatccgggatattggtgccatagctcaagtccatgcagagaatggtgacatcattgcagaggaacagcagaggatcctggatctgggcatcacaggccccgag 840

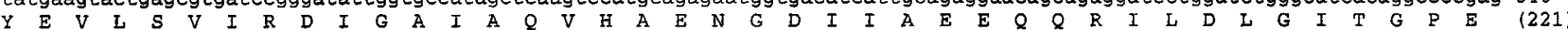
ggacacgtgctgagccggccagaggaggtcgaggctgaagctgtgaaccggtccatcaccattgccaatcagaccaactgcccgctgtatgtcaccaaggtgatgagcaayagtgctgcl 960

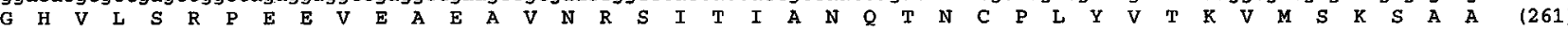
gaagtcatcgcccaggcacggaagaagggaactgtggtgtatggtgagcceatcactgccagcctggggactgatggctctcattattggagcaagaactgggccaaggccgctgccttt 1080

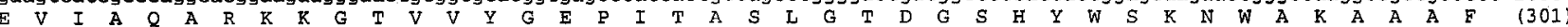
gtcacctctccaccettgagccccgacccaaccactccagactttctcaactcgttgctgtcctgtggagacctccaggtcactggcagtgcccactgtaccttcaacactgcccagaag 1200

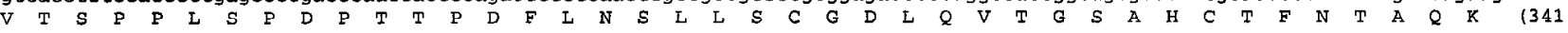
gctgtggggaaggataacttcaccttgattccagagggcaccaatggcactgaggagcggatgtctgtcatttgggataaagctgtggtcactgggaagatggacgagaaccagtttgtg 1320

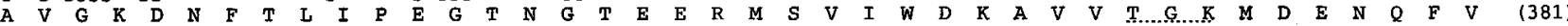

gctgtgactagcaccaacgcagccaaagtcttcaatctttacccacggaaaggtcgtatctccgtgggatctgacgcagacctggtgatctgggaccctgacagtgtgaagaccatctct 1440

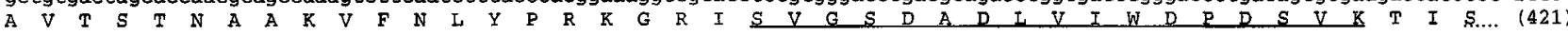
gccaagacgeacaacagtgctcttgagtacaacatctttgaaggcatggagtgtcggggctccccactggtggtcatcagccagggcaagattgtcctggaggacggcacgttgcatgtc 1560

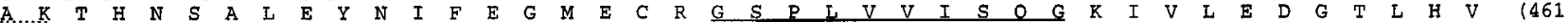
acggaaggctcaggacgctacattccccggaagcccttcctgactttgtgtacaaacgcatcaaggcaaggagcaggctggctgagctgaggggggtccctcgtggcctgtatgatgga 1680

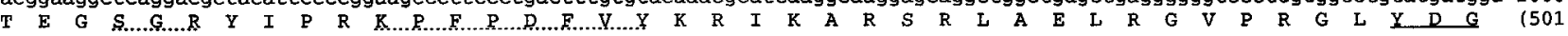
cccgtatgcgaggtgtctgtgacgcccaagacggtcactcoggcctcatcagctaagacatcccctgccaagcagcaggcgccacctgttcggaacctgcaccagtctggtttcagcttg 1800

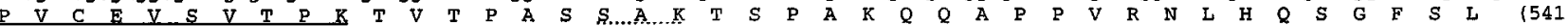
tctggtgctcagattgacgacaacattccccgccgcaccacccagcgcattgtggcgeccectggtggccgtgccaacatcaccagcctgggctaaagctcctaggcctgcaggccacgt 1920

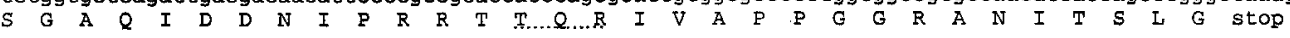

ggggatgggggatgggacacctgaggacattctgagacttccttccttccaattttttttccttttttgagagagcctgtgatagttgctgtgggcagccagttcctggggcttcctc 2040 ttgggcccctgcactcggtctcccctggagtttctgaattegetcacccaagtccctacacagtcatgaacaccacacccaagcccagccacccaccccacactgagctgcatccaaca 2160 tgcagacatgcgccaccatgcagatcccagcaagggtgccettatcacatccttggctgtgcagtcagcaccttcctgtcacggggaagatttagtgaattaccctgagctgccttcttt 2280 tcttttgaaaatttt aaaaatggttttctttgtgggactggggagggatgggggggtgggagtttttttttttaatactaaattgaaagtctgattcaatattaatccttgggtct 2400 gaactggacatcctaatgatcaattact aaccattaagctgattccgaggctggcaggctaccgccgcccctctggaaaggttccatgtgtctgtatcacccatcccttactcttctgg 2520 tcagctgttgagaagagactggtttttctttggcctagattttgcaacagattagacctttgaagttctctaccattttctgtgtctccggtctgttctggcttttcttctgcac 2640 tcttggagagatttagatgttggtctcctggtttgtgtttcttcgagacaatgtgcttttttccctggctttttgtttgttctcaaagccaggcatctgaatttggcctcagacacagcc 2760 tgagcggaccctagttttgacccccactccatagttttgtgctagcctggtgtctgtttaagattggtgctagctgattcecgteactaggaggtggetgagcttgaggcttgccagaca 2880 cagggatggtcctgattaagtcaccaatatgtcacatgtgggcccagataggtcacttgtggtggaa 2947

Figure 1. cDNA and deduced amino acid sequences of TOAD-64. The coding sequence for TOAD-64 is $1716 \mathrm{bp}$, which encodes a 572 amino acid protein. The deduced protein contains several potential protein kinase $\mathbf{C}$ phosphorylation sites and a tyrosine kinase phosphorylation site (dotted underlines). The four peptide sequences obtained by microsequence analysis of purified TOAD-64 protein are underlined. These sequence data are available from the EMBL Nucleotide Database under accession number Z46882.

mM EDTA in PBS or $2 \mathrm{M}$ urea in PBS. The samples were centrifuged as above, the supernatants saved, and the pellets washed with the appropriate buffer. Protease inhibitors were used in all buffers. Protein concentrations were determined by the method of Bradford (Bradford, 1976) using the Bio-Rad dye reagent kit and BSA as a standard.

Samples to be analyzed by immunoblotting were combined with gel loading buffer $(20 \mathrm{~mm}$ Tris-Cl, pH 6.8, 3\% SDS, $10 \%$ glycerol, $0.01 \%$ bromophenol blue) and b-mercaptoethanol $(0.05 \%)$, boiled for $5 \mathrm{~min}$ and electrophoresed by SDS-PAGE minigel (10\%) in $50 \mathrm{~mm}$ Tris base, $0.38 \mathrm{M}$ glycine, $0.2 \%$ SDS (Laemmli, 1970). The proteins werc clcctrophoretically transferred to nitrocellulose overnight at $50 \mathrm{~mA}$ in $25 \mathrm{~mm}$ Tris, $0.192 \mathrm{M}$ glycine, and $20 \%$ methanol (Towbin et al., 1979). The blots were blocked in Blotto (5\% nonfat dry milk in TBS) for $2 \mathrm{hr}$ and incubated in primary antibody (diluted in Dulbecco's modified Eagle's medium supplemented with $5 \%$ fetal calf serum, $0.2 \%$ Tween 20 , and $0.2 \%$ sodium azide) over night at room temperature. The blots were washed and incubated with alkaline phosphatase conjugated goat antirabbit IgG or goat anti-mouse IgG (Promega) for $2 \mathrm{hr}$ at room temperature. Immunoreactive bands were visualized with Nitro blue tetrazolium and 5-bromo-4-chloro-3-indolyl phosphate (Sigma).

Densitometry of blots stained with TOAD-64 antibody was used for quantification of the relative amounts of TOAD-64 in soluble and pellet fractions. Images of immunoblots were captured with a Hitachi CCD camera and imported into an Apple Macintosh Quadra 650 computer using a Scion LG-3 frame grabbing board. Imported images were an- alyzed with NIH Image V1.57 (Wayne Rasband, NIH). Integrated densities from each band were determined. For each extraction the percent of total (Fig. 10b) was determined by dividing the density of either the $\mathrm{S}$ or $\mathrm{P}$ bands by the sum of the integrated densities of both bands.

\section{Results}

Molecular cloning and sequence analysis of TOAD-64

The TOAD-64 protein is expressed at its highest levels during the first postnatal week. To clone the gene encoding the TOAD64 protein, first strand cDNA from postnatal day 5 (P5) rat cortex was used as a template for PCR amplification. Degenerate oligonucleotide primers were based on five peptide sequences obtained from microsequencing of purified TOAD-64 protein (peptide A: GAPLNSIXQG; peptide B: NHQSVAE, peptide C: YDGPVFDLTTTPK, peptide D: IAVGSDSDLVIWDPDAVK, peptide E: ALHVDIT). The primers were designed to encode only a portion of each peptide, so that a correct PCR product would be expected to contain the remainder of the peptide sequence. Of 12 possible primer combinations, one combination (representing peptide D and peptide $\mathrm{C}$ ) amplified a single major band of approximately $280 \mathrm{bp}$, while the others amplified mul- 
tiple minor bands or generated no PCR product. The major 280 bp PCR product was cloned into pCRII (Invitrogen) and sequenced. The predicted amino acid sequence from the region internal to both of the primers matched that of the original peptide fragments from the TOAD-64 protein. To obtain full length sequence, the $280 \mathrm{bp}$ PCR product was used to screen an E18 rat brain lambda ZAP II cDNA library. A total of $4.0 \times 10^{5}$ recombinant plaques were screened, resulting in 15 positive clones. The insert size of each of the clones was determined and redundant clones were eliminated by constructing a map of each clone using PCR with vector- and TOAD-specific primers. To obtain the $5^{\prime}$ end of the gene, an additional 200,000 recombinants were screened with a PCR product comprising the most $5^{\prime}$ end of the first set of clones. The composite sequence of TOAD-64 was obtained from four of these overlapping clones. The complete TOAD-64 coding sequence is 1716 bp (Fig. 1). The first in-frame methionine is preceded by a translational start consensus sequence, as described by Kozak (1984). An in-frame termination codon is found $30 \mathrm{bp}$ upstream of the translation initiation site. The TOAD-64 gene encodes a 572 amino acid long protein. Analysis of the deduced amino acid sequence shows no signal sequence or likely transmembrane domain, consistent with a cytoplasmic location for the protein. The sequence also has several (S/T) X (R/K) consensus sites for potential protein kinase $\mathrm{C}$ phosphorylation, as well as a potential tyrosine kinase phosphorylation site, (K) XXX (D) XX (Y), at Tyr-479 (Pearson and Kemp, 1991), suggesting that TOAD-64 is a phosphoprotein.

Several converging lines of evidence indicate that the gene we have cloned encodes the TOAD-64 protein. First, the isolated gene encodes a protein with a predicted molecular mass of 62,364 daltons and an isoelectric point $(\mathrm{pI})$ of 6.34 . These values are remarkably similar to the molecular mass $(64 \mathrm{kDa})$ and $\mathrm{pI}$ (6.4) of TOAD-64 (protein 310) on Iwo-dimensional SDS-PAGE (Geschwind and Hockfield, 1989). Second, four of the original five peptides obtained by amino acid sequence analysis are represented in the cDNA sequence (see Fig. 1). And third, synthetic peptides generated from a region of the sequence (residues 381399) that was not obtained in the original amino acid sequence analysis was used to immunize rabbits. Antisera to this new sequence recognizes TOAD-64 protein immunoprecipitated by one of the original antisera to TOAD-64 (data not shown). Together these data confirm that the isolated gene encodes the TOAD-64 protein.

Sequence similarity analysis using the GenBank and EMBL databases at both the nucleic acid and amino acid levels indicate that TOAD-64 is a previously unreported gene. The TOAD-64 gene product is homologous to the $u n c-33$ gene product of $C$. elegans. Over the entire length of the proteins, TOAD-64 and unc-33 show $34 \%$ identity, and as much as $79 \%$ similarity (Fig. $2 a$ ). C. elegans mutants in unc-33 have pronounced abnormalities in axonal arborizations, presumably due to errors in axonal branching and guidance during axonogenesis (Hedgecock et al., 1985; Li et al., 1992).

Substantial amino acid homology also exists between TOAD64 and six sequences isolated from a human fetal brain library using a random cloning strategy (Adams et al., 1993). Three of these map to overlapping stretches of the TOAD-64 gene, two map to a region in the $5^{\prime}$ end, and one to a region in the $3^{\prime}$ end of the gene. Over very long stretches, there is close to $100 \%$ identity between the TOAD- 64 gene and the human fetal brain sequences (Fig. $2 b-e$ ). The overlap and degree of similarity be-
A

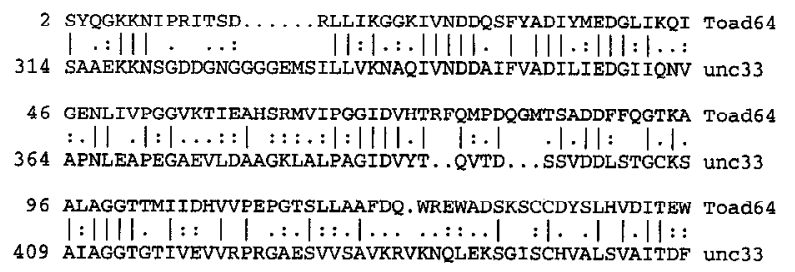

145 HKGIQEEMEALVKDHGVNSFLVYMAFKDRFQLTDSQIYEVLSVIRDIGAI TOad64 :: $:|\ldots|||:||:||:: \quad||||, \ldots: \mid::$ : : : :||: $459 \ldots$ CEQEMSELVKNEGINSFVL . . . . DGVSLTDDKLLELFEHVKRLGAL unc 33

195 AQVHAENGDI IAEEQQRILDLGITGPEGHVLSRPEEVEAEAVNRSITIAN TOAC64 $.|:|||:.|\quad:::| .||:|||| \mid$. ||||.:1|:|. ..::| 501 IRVVPENKSIVAMLEKKMLKLGVTGPEGFPQSRPESLEADRVSGVCVLGN unc33

245 QTNCPLYVTKVMSKSAAEVIAQARKKGTVVYGEPITASLGTDGSHYWSKN TOad64 $\ldots||: \ldots|| \ldots \ldots|\ldots||\cdot| .: \ldots:|.| . \ldots|| \mid .: 1 .=$ 551 LASCPISIVQVSSADSLAAIEKARASGALAHAEIASAAVTADGSALFSQD unc33 295 WAKAAAFVTSPPLSPDPTTPDFLNSLLSCGDLOVTGSAHCTFNTAQRAVG TOad64 601 LRFASAHLTDVPLRRGA $|.| \ldots|| \ldots:|| \ldots|| \ldots|:| \ldots||:. \ldots:$ 601 LRFASAHLTDVPLRRGA. PDRMIGALSTQPLVVCTSGHRPVNSATRVAA unC 33

345 KDNFTLIPEGTNGTEERMSVIWDKAVVTGKMDENQFVAVTSTNAAKVFNL TOad64 || $|.: \ldots| \ldots||||.|\cdot|:|:=|||:.:|| 1||||||||||:||$. 649 KD.FAIAQKGSTGAEERMAVVWERAVRSGRIDAMRFVAVTSTNAAKMFNM UnC33

395 YPRKGRISVGSDADLVIWDPDSVKTISAKTHNSALEYNIFEGMECRGSPL TOad64

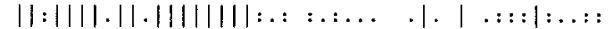

698 YPKKGRIAVGADADLVIWDASGKRVLESSRAQSSQENSMYDGLTVHSVVT unc 33

445 VVISQGKIVLEDGTLHVTEGSGRYIPRKPFPDFVYKRIKARSRLAELRGV TOad64

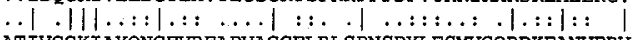
748 ATIVGGKIAYQNGEVREAPVAGGFLRLSPNSPYLFSMVGQRDKFANVERV unc 33 495 PRGLYDGPVCEVSVTPKTVTPASSAKTSPAKQQAPPVRNLHQSGFSLSGA TOAd64 798 ER...... $|$.$| EASSOOOKPOONGHHKNSGDFDRNRT . . KVMESSIDFGGS unc33$ 545 QIDDNIPRRTTQRIVAPPGGRAN TOAO B.3. $\ldots \ldots \ldots$ AANRPRNPPGGRTT une33

$\mathbf{B}$

-21 FPALFALKLSS *NYF PPPPGEMSYQGKKNIPRITSDRLLIKGGKIVNDDQ 29

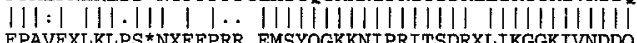
FPAVEXLKLPS NXFFPRR. EMSYQGKKNIPRITSDRXLIKGGKIVNDDQ T07524

30 SFYADI YMEDGLIKOIGENLIVPGGVKTIEAHSRMVIPGGIDVHTRF.QMPDQG 82

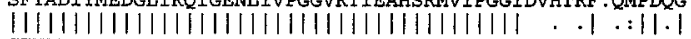
SFYADIYMEDGLIKQIGENLIVPGGVKTIEAHSRMVIPGGI*RPHSFSRLPDPG T07524

C

63 RMVIPGGIDVHTRFOMPDQGMTSADDFFQGTKAALAGGTTMI IDHVVPEPGT 114 |||||||||||||||||||||||||||||||||||||||||||||||||||| RMVIPGGIDVHXRFQMPDQGMTXADDFFQGTKAALAGGTTMIIDHVVPEPGT T06278

$\mathbf{D}$

367 DKAVVTGKMDENQFVAVTSTNAAKVFNLYPRKGRISVGSDADLVIWDPDS 416 KKTVATGKMDENQEVAVTSTANAAKIFNLYYRKGRIAVGSDADVVIWDPDK T08129

417 VKTISAKTHNSALEYNIFEGMECRGSPLVVISOGKIVLEDGTLHVTEGSG 466 $:||||.|\cdot| .||:||||||||||:|||||||||||||:||| .::|\ldots| \mid$ LKTITAKSHKSAVEYNIFEGMECHGSPLVVISOGKIVFEDGNINVNKGMG T08129

467 RYIPRKPFPDFVYKRIKA 484 $::|||l| l:$
RFIPRKAFPE. . OPVPA RFIPRKAFPE. . QPVPA T08129

$\mathbf{E}$

514 TPASSAKTSPAKOOAPPVRNLHOSGFSLSGAOIDDNIPRRTTORIVAPPG 563

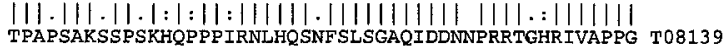

564 GRANITSLG 572 $|1| 1||||$.

GRSNITSLG T08139

Figure 2. The predicted amino acid sequence of TOAD-64 is homologous to the $C$. elegans unc-33 gene $(A)$ and to several human fetal brain cDNAs $(B-E)$. $A$, The predicted amino acid sequences for TOAD64 and $u n c-33$ ( $\mathrm{Li}$ et al., 1992) are shown aligned. Solid lines between the two sequences represent identical sequence and dots indicate conserved substitutions. The two proteins are $34 \%$ identical over the entire coding region and possess many conserved substitutions. $B$ and $C$, The first 114 coding amino acids of TOAD-64 are nearly identical to human sequences T07524 (EMBL accession number) and T06278. The initiating methionine is indicated in bold. $D$ and $E$, The homology between TOAD-64 and the human clones continues through the length of the protein, and ranges between 74-95\% identity. The human sequence, T08129, shown in $D$ is also found in sequences T06728 and T09404. 


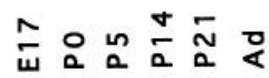

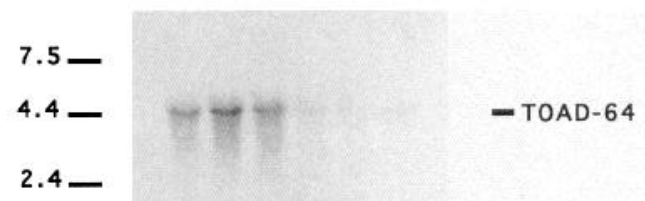

\section{$\bullet \bullet \bullet \bullet \bullet$}

Figure 3. TOAD-64 mRNA is neural specific and developmentally regulated. Total RNA $(25 \mu \mathrm{g})$ from E17, P0, P5, P14, P21, and adult rat cortex $(A)$ and from $\mathrm{P} 21$ rat liver, kidney, and spleen $(B)$ were probed for TOAD-64 mRNA. A single $4.5 \mathrm{~kb}$ transcript is detected in the cortex at E17, continues to be expressed during the first postnatal week (P5), and subsequently declines during the second postnatal week to a level that is nearly undetectable in the adult. $B$, TOAD-64 mRNA is not detected in non-neural tissues. Even after over exposure, no TOAD-64 mRNA was detected in liver, kidney, or spleen. Both filters were simultaneously hybridized with a probe for the nondevelopmentally regulated gene, cyclophilin $(c y c)$, to verify equal RNA loading levels.

tween these six gene fragments and the TOAD-64 gene suggests that all six fragments represent multiple sequences from a single gene or a gene family. These human fetal brain sequences have not been characterized, but it can be predicted that they represent the human homologue(s) of rat TOAD-64. The very high degree of conservation between rat and human could suggest that TOAD-64 has a highly conserved, essential function.
TOAD-64 mRNA is enriched in the nervous system and is developmentally regulated

Two different partial sequences from the TOAD-64 gene, representing bases 530-1215 and 1220-1533, were used to study the regulation and distribution of TOAD- 64 mRNA. Northern analysis shows that a single band at $4.5 \mathrm{~kb}$ representing the TOAD-64 mRNA is developmentally regulated (Fig. 3a). TOAD-64 mRNA is detected in brain at E17. The levels increase up to postnatal day 5 (P5), and subsequently decline to an almost undetectable level in the adult. No TOAD-64 message is detectable in the non-neural tissues sampled (Fig. $3 b$ ). The pattern of regulation of the TOAD- $64 \mathrm{mRNA}$ parallels that previously described for the TOAD-64 protein (Minturn et al., 1995).

In situ hybridization confirms both the developmental regulation and the neural specificity of TOAD-64 mRNA (Fig. 4). TOAD-64 mRNA is abundant throughout the neuraxis at E14. Hybridization signals are high in both the CNS and PNS. In the PNS, sensory and autonomic ganglia express TOAD-64. No hybridization is detected outside of the nervous system. In the CNS, all regions of the brain and spinal cord express TOAD64 , although the distribution within each area indicates that not all cells within the CNS are TOAD-64 positive (see below). As development proceeds, hybridization remains high through the first postnatal week, but then declines to an almost undetectable level in most areas of the brain by postnatal day 14 (P14). The only area of the CNS in which TOAD-64 mRNA is detected in adults is the hippocampus. Antibody to TOAD-64 shows that the adult dentate gyrus contains a small population positive cells, whose position and morphology matches that of the dentate neurons that are born in adult rats (Bayer, 1982). Antibody staining also reveals TOAD-64 protein expression in the primary afferents to the olfactory bulb in adult animals, axons from neurons that continue to be generated in the adult (Graziadei and Monti-
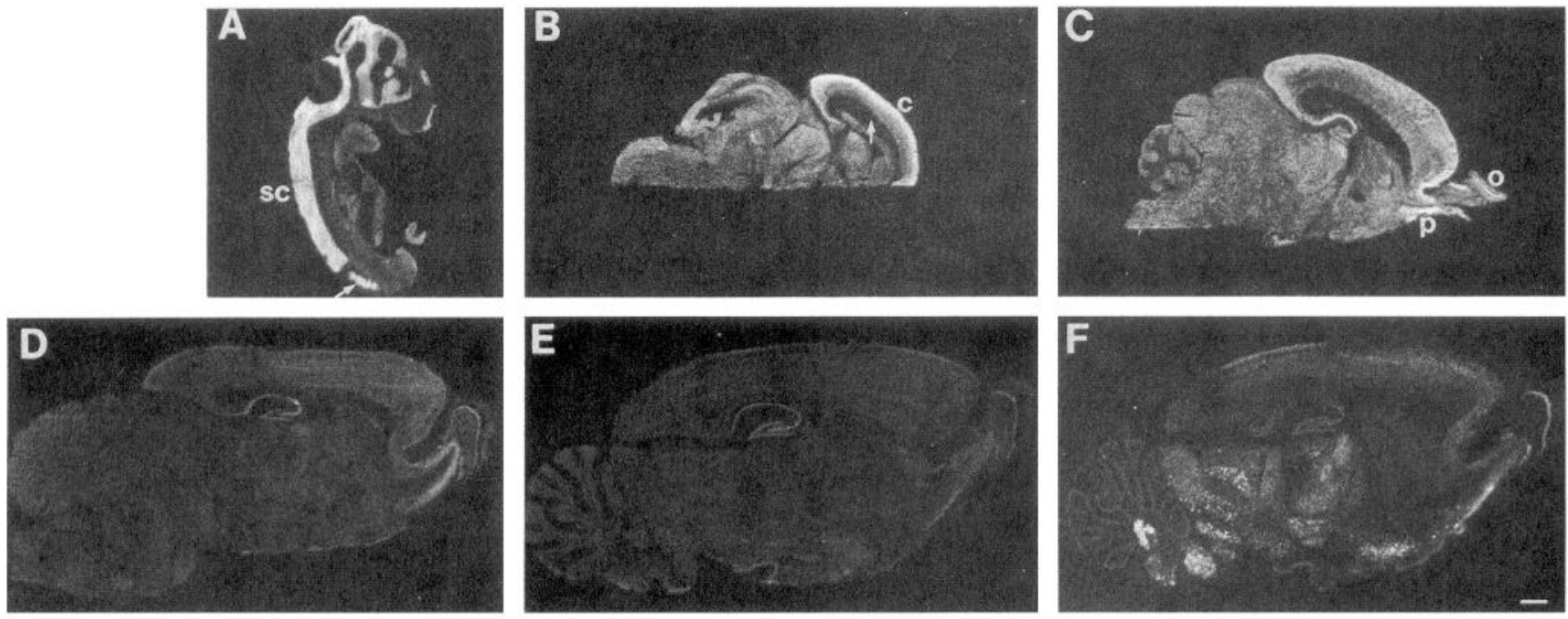

Figure 4. In situ hybridization confirms the neural specificity of TOAD-64 and demonstrates the broad distribution of TOAD-64 in the developing brain. Parasagittal sections from E14 $(A), \mathrm{P} 0(B), \mathrm{P} 5(C), \mathrm{P} 14(D)$, and $\mathrm{P} 21(E)$ rats were hybridized to a ${ }^{35}$ S-labeled cRNA probe for rat TOAD64 and the middle subunit of neurofilament $(F)$ as a control. $A$, At E14, TOAD-64 mRNA is detected throughout the developing brain and spinal cord $(s c)$, and in the dorsal root ganglia (arrow) of the peripheral nervous system. B. At P0 TOAD-64 hybridization is detected throughout the brain, with a particularly high level of signal in the neocortex $(c)$. The hybridization signal in the neocortex is not uniform; labeling is high in the developing cortical plate and far lower in the ventricular zone (arrow) (see also Fig. 6). $C$, At P5, hybridization is still high in the neocortex as is labeling in the olfactory bulb $(o)$ and pyriform cortex $(p)$. D. At P14, hybridization throughout the brain is reduced. $E$, By P21, the expression of TOAD-64 mRNA is almost undetectable. $F$, At P21, neurofilament mRNA is abundantly expressed in differentiated neurons throughout the CNS. Scale bar, $1 \mathrm{~mm}$. 

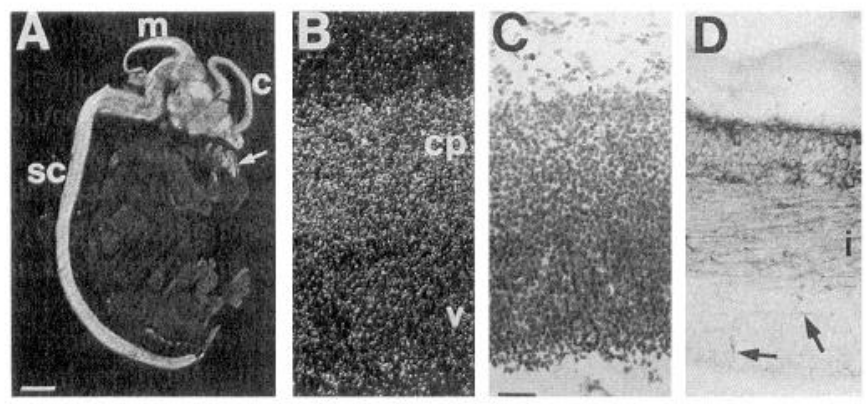

Figure 5. In the developing cortex, TOAD-64 is expressed in the cortical plate, which contains postmitotic neurons, but not in the mitotic cells of the ventricular zone. Parasagittal sections of E17 rat embryos were hybridized with TOAD-64 antisense cRNA probe $(A$ and $B)$, and stained with cresyl violet $(C)$, or, sections were stained with TOAD-64 antiserum $(D)$. A, A view of the whole embryo demonstrates the restriction of TOAD-64 mRNA expression to the nervous system. Hybridization is abundant in the spinal cord $(s c)$, midbrain $(m)$, and neocortex $(c)$. Signal is also detected in the olfactory epithelium (arrow). $B$, An emulsion-dipped section viewed under dark-field illumination shows that in the E17 cortex, hybridization signal is most abundant in the cortical plate $(c p)$. The ventricular zone $(v)$, though very cell dense (compare with panel $C$ ), has a far lower density of silver grains. $C$, Cresyl violet staining shows the relative cell densities of each layer of the E17 neocortex. $D$, Antibody staining of the cortex shows that the TOAD-64 protein has a very similar distribution to that of the mRNA. Antibody staining is largely restricted to the intermediate zone and the developing cortical plate. The ventricular zone is largely unstained, with the exception of a few process-bearing cells (arrows) that appear to be migrating into the intermediate zone $(i)$.

Graziadei, 1978). While we have not examined the nasal sinuses in adult animals, in embryos TOAD- 64 mRNA is present in the olfactory epithelium (Fig. $5 a$ ).

In a previous report we showed that the TOAD-64 protein is first expressed by neurons shortly after they have completed their final mitosis (Minturn et al.,1995). It was important to determine if this pattern of protein expression reflected transcriptional or translational regulation. In situ hybridization shows clearly that TOAD-64 mRNA, like TOAD-64 protein, is not detected in the ventricular zone of the developing brain. For example, in the cortex at E17, the highest level of hybridization is seen in the cortical plate (Fig. $5 b$ ), with far lower levels of hybridization in the ventricular and subventricular zones, similar to the distribution of the protein (Fig. $5 d$ ). These results indicate that the restricted expression of the protein to newly born neurons is likely to be controlled at the level of gene transcription.

\section{TOAD-64 is expressed by P19 and PC12 cells coincident with neuronal differentiation}

In the developing brain TOAD-64 is expressed only by cells that have undergone a commitment to a neuronal phenotype. To address the possible association of TOAD-64 expression with neuronal differentiation, we examined the expression of TOAD-64 in two cell lines that can be induced to assume a neuronal phenotype, the embryonal carcinoma cell line, P19, and the rat pheochromocytoma cell line, PC12.

P19 cells are developmentally pluripotent (Edwards and McBurney, 1983). P19 cells exposed to retinoic acid (at greater than $3 \times 10^{-7} \mathrm{M}$ ) develop neural properties: by $6 \mathrm{~d}$ after exposure to retinoic acid approximately $85 \%$ of cells express neuronal markers (McBurney et al., 1988; Staines et al., 1994). We examined undifferentiated and retinoic acid differentiated P19 cells by Northern analysis (Fig. 6a). Prior to neural induction, TOAD-

\section{A P19}

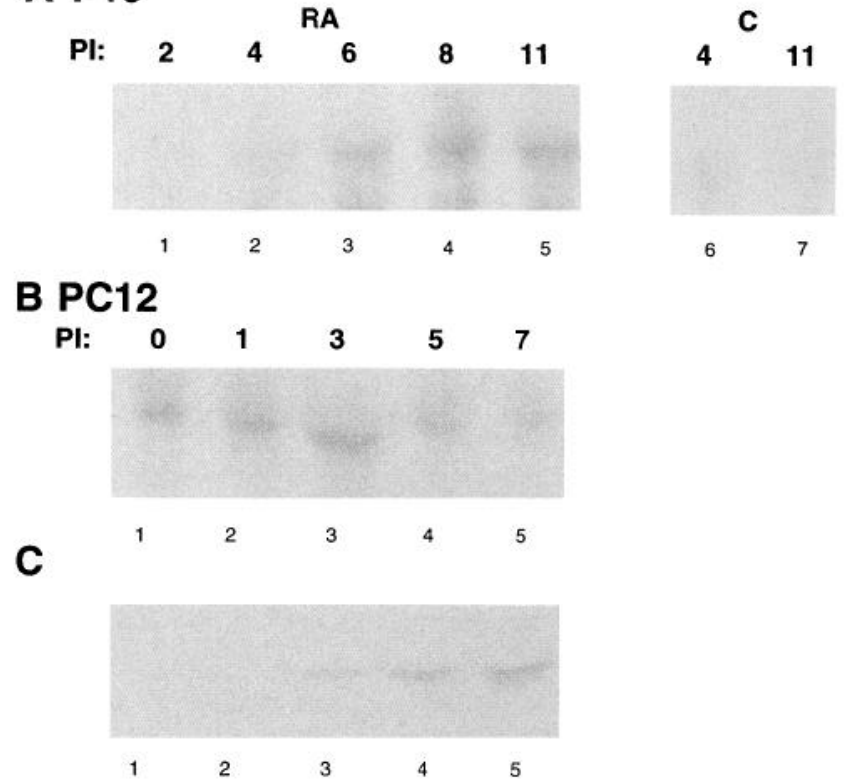

Figure 6. TOAD-64 is regulated in parallel with neuronal differentiation of P19 and PC12 cells. A, Total RNA ( $40 \mu \mathrm{g} / \mathrm{lane})$ from retinoic acid induced $(R A)$ or control $(C)$ cultures of $\mathrm{P} 19$ embryonal carcinoma cells were probed for TOAD-64 mRNA expression. TOAD-64 mRNA is not detected at $2 \mathrm{~d}$ after induction (lane 1 ), but is detected at increasing levels after 4, 6, 8, and $11 \mathrm{~d}$ of retinoic acid treatment (lanes 2-5). Control cells at 4 or $11 \mathrm{~d}$ in culture do not express TOAD-64 mRNA (lanes 6 and 7). B, Total RNA ( $35 \mu \mathrm{g} / \mathrm{lane}$ ) from PC12 pheochromocytoma cells probed for TOAD-64 mRNA shows that prior to (lane 1 ) or in the days following induction with NGF (PI; lanes 2-5) TOAD64 mRNA is expressed. $C$, In contrast to the mRNA, Western blots of protein from uninduced (lane 1) or NGF-induced (lanes 2-5) PC12 cells show that prior to (lane 1 ) or $1 \mathrm{~d}$ after (lane 2) NGF induction, little TOAD-64 protein is detected. Three days following NGF-induction (lane 3) TOAD-64 protein is detected on Western blots and increases gradually thereafter (lanes 4 and 5 ).

64 mRNA is not expressed, but exposure to retinoic acid induces the expression of TOAD-64 mRNA.

PC12 cells are an adrenal chromaffin-derived tumor cell line (Tischler, 1975; Greene and Tischler, 1976), that, when grown in the absence of nerve growth factor (NGF), proliferate and do not assume neuronal properties. When NGF is added to the culture medium, $\mathrm{PC} 12$ cells differentiate into cells with neuronal properties, including the cessation of mitotic activity, neurite extension, and the expression of genes associated with mature neurons (Tischler, 1975; Stein et al., 1988; Vetter and Betz, 1989; Sano et al., 1990). TOAD-64 expression was assayed in uninduced and NGF-induced PC12 cells. In contrast to P19 cells, $\mathrm{PC} 12$ cells, in the absence of any induction by NGF, express TOAD-64 mRNA (Fig. 6b). Furthermore, there is no apparent upregulation of mRNA following NGF induction. The disparity between the behavior of TOAD- 64 mRNA in these two cell types prompted us to examine the expression of TOAD-64 protein in PC12 cells (Fig. $6 c$ ). In the absence of NGF, little TOAD64 protein is detected. After NGF addition, the amount of TOAD-64 increases at $24 \mathrm{hr}$ and continues to increase up to 5 $\mathrm{d}$. These results suggest that the TOAD-64 protein is involved in the neuronal differentiation of PC12 cells, perhaps in the elaboration of neurites. However, in $\mathrm{PC} 12$ cells, in marked contrast to both P19 cells and to neurons in vivo, TOAD-64 protein expression is not transcriptionally regulated. 

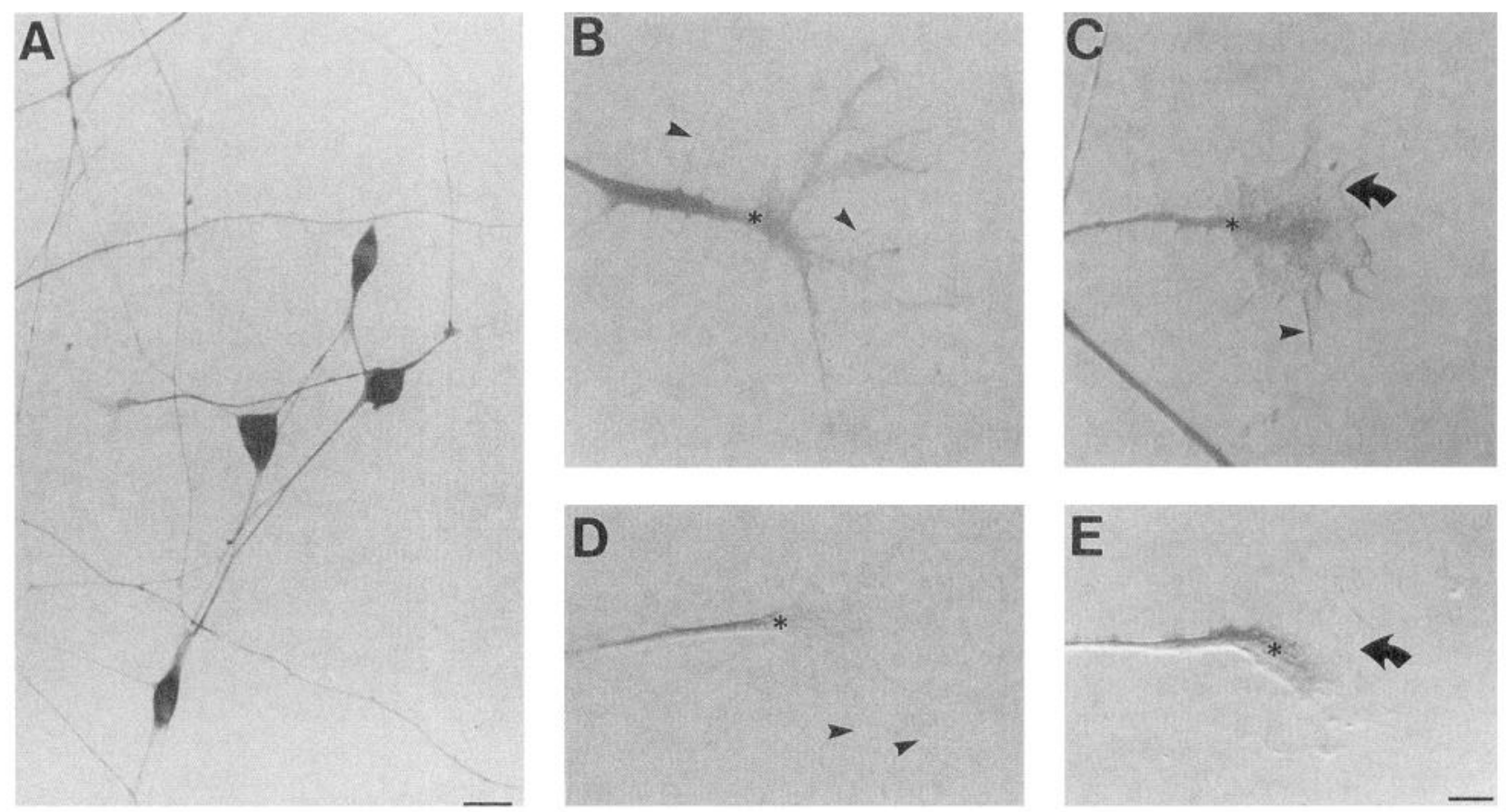

Figure 7. TOAD-64 is present in the lamellipodia of growth cones in primary neuronal cultures. A, In primary cultures of rat dorsal root ganglion neurons, TOAD-64 is present in the cell bodies and processes of neurons. $B$ and $C$, TOAD-64 immunoreactivity is detected throughout the growth cone. The darkest staining for TOAD-64 is seen in the distal part of the neurite, just as the neurite gives rise to the growth cone (asterisks). TOAD64 immunoreactivity extends into the growth cone itself, with staining present at the leading edge of the lamellipodia (curved arrow in C). Even many of the fine filopodia that arise from the growing tip of the neurite contain TOAD-64 protein (arrowheads). $D$ and $E$, In contrast to the distribution of TOAD-64 in the growth cone, immunoreactivity for class III $\beta$-tubulin is restricted to the axon and only the most proximal portion of growth cones (asterisks). Class III $\beta$-tubulin is not observed either in the distal part of the growth cone (curved arrow in E) or in the filopodia (arrowheads in D). Scale in $A=20 \mu \mathrm{m}$; scale in $B-E=5 \mu \mathrm{m}$.

\section{TOAD-64 is present in growth cones}

To determine whether TOAD-64 might have a role in the mechanisms by which axons advance toward their targets, we examined the distribution of the TOAD- 64 protein in neurons in primary culture. In cultures of dorsal root ganglion cells or cortical neurons grown on a polyornithine-laminin substrate, growth cones can be easily identified after $20 \mathrm{hr}$ in culture. Immunohistochemical analysis shows that TOAD-64 is expressed in neuron cell bodies and processes (Fig. 7a). TOAD-64 immunoreactivity is present along the full length of the axon into the growth cone. In the growth cone immunoreactivity is most intense at the center of the growth cone, but it also extends through the lammellipodia to the edges of the lammellipodial veil (Figs. $7 b, c ; 8 a, c)$. Often a region of particularly intense immunoreactivity for TOAD-64 is observed in the fine filopodial extensions from the growth cone. The distribution of TOAD-64 in the growth cone is different from the cytoskeletal protein, class III $\beta$-tubulin (Figs. $7 d, e ; 8 b, d$ ), which does not extend into the lamellipodia or filopodia.

\section{TOAD-64 is reexpressed following peripheral axotomy}

The possibility that TOAD-64 might play a role in the growth of axons led us to examine its expression during axon regeneration in adult animals. Following lesions of the sciatic nerve, sciatic motor neurons with cell bodies in the spinal cord can regenerate axons toward their target muscles. Expression of the TOAD-64 protein by the sciatic motor neurons was studied following a sciatic nerve crush. In normal adult animals, there is no detectable TOAD-64 expression by motor neurons. Follow- ing sciatic nerve crush, TOAD-64 protein is expressed in sciatic motor neurons (Fig. $9 b$ ). The unlesioned, contralateral, motor neurons do not express the protein (Fig. 9a). A time course of the reexpression of TOAD-64 following nerve injury reveals expression of TOAD-64 protein as early as $1 \mathrm{~d}$ after nerve crush.

\section{TOAD-64 is a membrane associated protein}

While the sequence of TOAD-64 does not contain a transmembrane domain, biochemical experiments demonstrate that TOAD64 has a membrane associated form. Two-dimensional gel analyses showed that TOAD-64 partitions with a soluble fraction, which contains cytoplasmic constituents, as well as with a particulate fraction, which contains membrane and cytoskeletal elements. Western blot analysis of a P12 cortical homogenate using antisera to TOAD-64 provides further evidence that TOAD-64 has both soluble and particulate forms (Fig. 10a).

To determine the mechanism of association with the pellet fraction, further extractions were performed (Fig. 10). Extraction of the pellet with PBS or with $2 \mathrm{M} \mathrm{NaCl}$ releases only $20 \%$ of the TOAD-64 from the particulate fraction. TOAD-64 is not bound to the insoluble fraction through $\mathrm{Ca}^{2+}$-dependent mechanisms, because extraction of the particulate fraction with EDTA also releases only $20 \%$ of the protein. In contrast, treatment of the particulate fraction with $2 \mathrm{M}$ urea releases $50 \%$ of the protein, and $90 \%$ of the protein is extracted with $1 \%$ Triton X-100. Efficient extraction with Triton makes it unlikely that TOAD-64 is associated with the particulate fraction by binding to the Triton insoluble cytoskeleton. The fact that over $90 \%$ of the TOAD-64 protein can also be extracted with $\mathrm{Na}_{2} \mathrm{CO}_{3}$ indicates that it is 

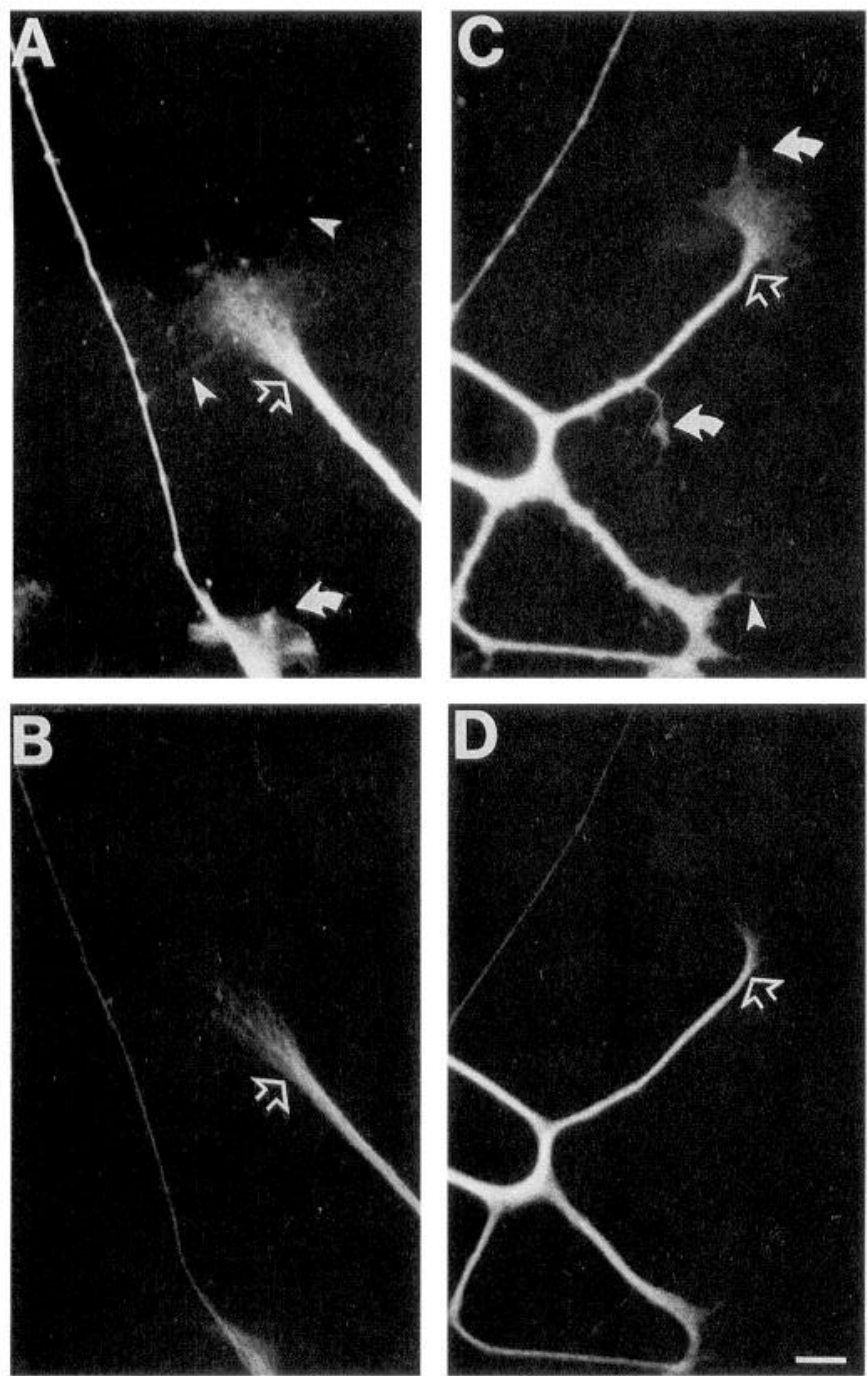

Figure 8. Double labeling shows that TOAD-64 is present in lamellipodia and filopodia of growth cones. Primary cultures of dorsal root ganglion neurons were stained for TOAD-64, visualized with FITC ( $A$ and $C$ ), and for class III $\beta$-tubulin, visualized with Texas red ( $B$ and $D$ ). The same field is shown under FITC optics for TOAD-64 in A and under Texas red optics for class III $\beta$-tubulin in $B$. Similarly, the same field is shown in $C$ and $D$. $A$ and $C$, TOAD-64 immunoreactivity is detected throughout the neurite and into the growth cone. Intense staining for TOAD-64 is seen in the distal part of the neurite, just as the neurite gives rise to the growth cone (open arrows). TOAD-64 immunoreactivity extends into the growth cone itself, with staining often present at the leading edge of the lamellipodia (curved arrows). Many of the fine filopodia that arise from the growing tip of the neurite contain TOAD-64 protein (arrowheads). $B$ and $D$, In contrast to the distribution of TOAD-64 in the growth cone, immunoreactivity for class III $\beta$-tubulin is restricted to the neurite and only the most proximal portion of growth cones (open arrows). Class III $\beta$-tubulin is not observed either in the distal part of the growth cone or in the filopodia. Scale $=10$ $\mu \mathrm{m}$.

either a peripheral membrane protein or trapped within vesicles. Both the amino acid sequence deduced from the nucleic acid sequence, which does not contain a putative transmembrane domain, and the immunohistochemical localization of the protein to the cytoplasm (Minturn et al., 1995), further indicate that TOAD-64 is an intracellular protein. Together these data show that the particulate form of TOAD-64 is likely to be tightly
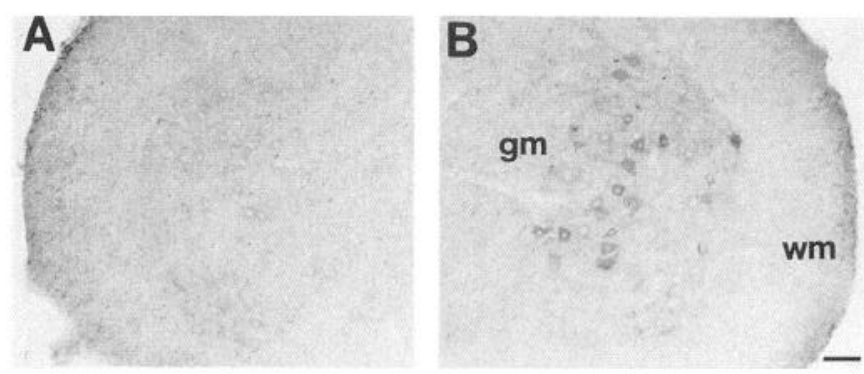

Figure 9. In adult animals, TOAD-64 is reexpressed in spinal cord motor neurons following a peripheral axotomy. Five days following sciatic nerve crush, TOAD-64 is detected ipsilateral to the lesion $(B)$, but not contralateral to the lesion $(A)$. $A$, If the sciatic nerve is intact, antisera to TOAD-64 does not stain motor neurons in the ventral horn of the spinal cord. $B$, The sciatic motor neurons on the side of the nerve crush show staining with TOAD antisera, indicating a reexpression of the protein after injury, coincident with axon regeneration. $w m=$ white matter; $g m \times=$ gray matter; Scale bar, $100 \mu m$.

associated with a membrane protein, and not itself a transmembrane protein.

\section{Discussion}

We report here the full length sequence and expression pattern of a gene, TOAD- 64 , that is initially transcribed at the earliest stages in neuronal differentiation. Neither the TOAD-64 protein nor its mRNA is expressed by mitotically active progenitors in the ventricular zone, but both are expressed by postmitotic neu-

A

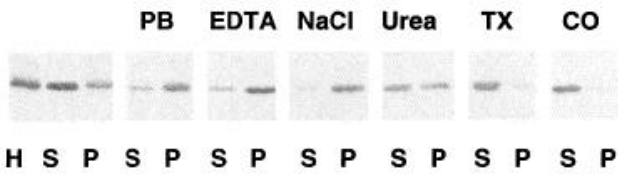

B

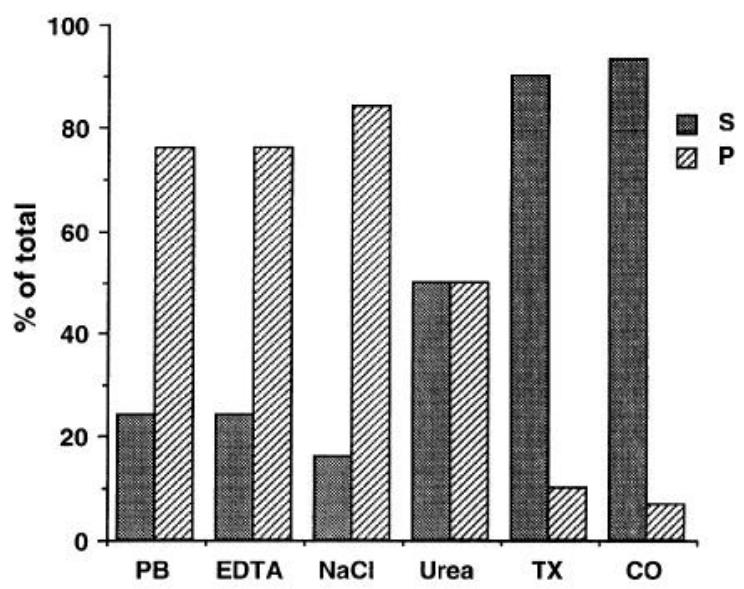

Figure 10. Extraction conditions for TOAD-64 demonstrate that it is membrane associated. $A$. Homogenates from $\mathrm{P} 12$ rat cerebral cortex $(H)$ were separated into soluble $(S)$ and pellet $(P)$ fractions by centrifugation at $100,000 \times g$ for $1 \mathrm{hr}$. The pellet fraction was rehomogenized in PBS and divided into six separate aliquots that were recentrifuged. After resuspending the aliquots in either $0.1 \mathrm{M} \mathrm{Na}_{2} \mathrm{CO}_{3} \mathrm{pH} 11(\mathrm{CO})$, PBS $(\mathrm{PB}), \mathrm{PBS}+2 \mathrm{M} \mathrm{NaCl}(\mathrm{NaCl}), \mathrm{PBS}+10 \mathrm{~mm}$ EDTA, PBS $+2 \mathrm{M}$ urea, or $\mathrm{PBS}+1 \%$ Triton $\mathrm{X}-100$, soluble and pellet fractions were once again generated. Immunoblots of the protein extracts were then probed with the antibody to TOAD-64. $B$, The relative amount of TOAD-64 in the soluble or pellet fractions was quantified using densitometry. 
rons. TOAD-64 is one of the few known genes that is turned on coincident with the very earliest events in neuronal differentiation. The regulation of TOAD-64 in parallel with axon elongation in several different paradigms, together with its localization to lamellipodia and filopodia of growth cones, suggests a role for this protein in axonogenesis.

The TOAD-64 gene encodes a deduced protein with a molecular mass of 62,364 and $\mathrm{pI}$ of 6.34 , almost identical to the estimates for the protein from two-dimensional gels (Geschwind and Hockfield, 1989). The TOAD-64 gene shows significant homology to the $C$. elegans unc-33 gene. unc-33 was originally isolated in a screen for motorically uncoordinated mutants. Further histological analysis revealed that all neurons in unc-33 mutants have defective patterns of axon outgrowth (Hedgecock et al., 1985; Li et al., 1992). In unc-33 mutants, axons terminate prematurely, have abnormal branch points and follow inappropriate routes (Hedgecock et al., 1985; Desai et al., 1988; Siddiqui and Culotti, 1991; Li et al., 1992). Based on axonal morphology, it was predicted that unc-33 would encode a cytoskeletal protein, such as a microlubule associated protein (Hedgecock et al., 1985), but subsequent sequence analysis revealed that, like TOAD-64, unc-33 showed no homology to any protein already in the database ( $\mathrm{Li}$ et al., 1992). The unc-33 product is predicted to have several potential phosphorylation sites, consistent with the fact that the TOAD-64 gene sequence contains consensus sites for serine, threonine, and tyrosine phosphorylation. In addition, unc-33 lacks a transmembrane region or signal peptide, as does TOAD-64. The major difference between unc33 and TOAD-64 is that unc-33 has three transcripts, while we have detected only one for TOAD-64. The size of the largest predicted unc- 33 protein, $90 \mathrm{kDa}$, is significantly larger than TOAD-64; however, the unc-33 protein(s) itself has not been isolated or characterized. Nevertheless, the sequence and predicted structural similarities between the unc-33 gene product and TOAD-64 suggest that they are related, and perhaps homologous, proteins from evolutionarily distant species. This provides support for the possibility that TOAD-64 may, like unc33. play a critical role in axon outgrowth in rodents.

Our previous work led to the suggestion that TOAD-64 might participate in early neuronal differentiation, such as in cell migration or axon outgrowth (Minturn et al., 1995). Antibodies to TOAD-64 showed that the protein is first expressed by neurons shortly after the final mitosis, at a time when neurons are just beginning their migration out of the ventricular zone. TOAD- 64 expression precedes that of several neuronal markers, including neurofilament and MAP2. Double labeling with an antibody to class III $\beta$-tubulin showed that all postmitotic neurons express TOAD-64. The in situ hybridization analyses presented here indicate that the TOAD-64 gene, like the protein, is not expressed in the region occupied by progenitor cells, but is first detected outside of the ventricular zone. These data on the expression of TOAD-64 mRNA demonstrate that the regulation of TOAD-64 protein in the developing brain is at the level of gene transcription. Unlike most previously described neuronal genes and proteins, TOAD-64 mRNA is downregulated to an almost undetectable level in most regions of the adult brain. The decline in TOAD-64 expression during the second postnatal week coincides with the end of the major period of axon growth, suggestive of a role in neurite extension.

TOAD-64 expression in cell lines further underscores its regulation in parallel with neuronal differentiation and axon outgrowth. TOAD-64 mRNA is not detected in the embryonal car- cinoma cell line, P19, prior to the induction of a neuronal phenotype. Induction of neuronal properties by retinoic acid induces the expression of TOAD-64 mRNA. In PC12 cells, neuronal differentiation apparently increases the rate of translation or the stability of the TOAD- 64 mRNA or protein without altering the constitutive expression of TOAD-64 mRNA. This kind of protein regulation is similar to that observed for other neuronal proteins in PC12 cells (Sharma et al., 1993). Although the mechanism of regulation of protein levels is different in P19 and PC12 cells, it appears likely in both cases that TOAD-64 protein plays a role in the acquisition of a neuronal phenotype, potentially in mediating neurite outgrowth.

$\Lambda$ role in neurite outgrowth is also suggested by the localization of TOAD-64 to the lamellipodia and filopodia at the advancing edge of growth cones. Moreover, further evidence supporting such a role comes from our experiments on axon regeneration. Reexpression during axon regeneration would be predicted for a protein required for axon outgrowth or navigation. During development, TOAD-64 is expressed at a high level in the spinal cord. In the normal adult spinal ventral horn, as in most other areas of the adult CNS, there is little detectable TOAD-64. Motor neurons with axons in the sciatic nerve reexpress TOAD-64 as they regenerate to find targets following a sciatic nerve lesion. Protein upregulation during axon regeneration has also been demonstrated for GAP-43 (Skene and Willard, 1981), a protein known to be associated with axonal elongation. Also consistent with a role in axonogenesis is the expression of TOAD-64 in areas of the adult brain that have the capacity for ongoing neurogenesis and axon growth.

A membrane-associated protein expressed during axonal extension and localized at lamellipodia would be optimally situated to participate in the signal transduction processes that permit growing axons to choose correct routes and targets. The nucleic acid sequence of TOAD-64 encodes a protein that lacks a signal sequence or a transmembrane domain, dictating that the TOAD64 protein is cytoplasmic. However, extraction experiments demonstrate that the protein has both soluble and membraneassociated forms. The mechanism by which TOAD-64 associates with the membrane fraction is not apparent from the sequence alone. Biochemical experiments show that conditions that extract transmembrane proteins and proteins associated with them can release TOAD-64 from a crude membrane preparation. It is therefore likely that TOAD-64 binds noncovalently with high affinity to a membrane protein. A membrane localization might be predicted for a protein that participated in the cellular machinery by which axons navigate to reach their targets. While definitive demonstration of the function of TOAD-64 still lies before us, the data presented here and previously (Geschwind and Hockfield, 1989; Minturn et al., 1995) suggest that TOAD64 could be a central element in the complex machinery underlying axonal outgrowth and pathfinding.

\section{References}

Adams MD, Soares MB, Kerlavage AR, Fields C, Venter JC (1993) Rapid cDNA sequencing (expressed sequence tags) from a directionally cloned human infant brain cDNA library. Nat Genet 4:373-380.

Bayer SA (1982) Changes in the total number of dentate granule cells in juvenile and adult rats: a correlated volumetric and ${ }^{3} \mathrm{H}$-thymidine autoradiographic study. Exp Brain Res 46:315-323.

Bradford MM (1976) A rapid and sensitive method for the quantitation of microgram quantities of protein utilizing the principle of proteindye binding. Anal Biochem 72:248-254.

Church GM, Gilbert W (1984) Genomic scquencing. Proc Natl Acad Sci USA 81:1991-1995. 
Danielson P, Forss-Petter S, Brow MA, Calavetta L, Douglass J, Milner RJ, Sutcliffe JG (1988) p1B15: a cDNA clone of the rat mRNA encoding cyclophilin. DNA 7:261-267.

Desai C, Garriga G, McIntyre SL, Horvitz HR (1988) A genetic pathway for the development of Caenorhabditis elegans HSN motor neurons. Nature 336:638-646.

Easter SS, Ross LS, Frankfurter A (1993) Initial tract formation in the mouse brain. J Neurosci 13:285-299.

Edwards MKS, McBurney MW (1983) The concentration of retinoic acid determines the differentiated cell types formed by a teratocarcinoma cell line. Dev Biol 98:187-191.

Feinberg AP, Vogelstein B (1983) A technique for radiolabeling DNA restriction endonuclease fragments to high specific activity. Anal Biochem 132:6-13.

Geschwind DH, Hockfield S (1989) Identification of proteins that are developmentally regulated during early cerebral corticogenesis in the rat. J Neurosci 9:4303-4317.

Graziadei PPC, Monti-Graziadei GA (1978) Continuous nerve cell renewal in the olfactory system. In: Handbook of sensory physiology, Vol IX, Development of sensory systems (Jacobson M, ed), pp 5583. New York: Springer.

Greene LA, Tischler AS (1976) Establishment of a noradrenergic clonal line of rat adrenal pheochromocytoma cells which respond to nerve growth factor. Proc Natl Acad Sci USA 73:2424-2428.

Hedgecock EM, Culotti JG, Thomson JN, Perkins LA (1985) Axonal guidance mutants of Caenorhabditis elegans identified by filling sensory neurons with fluorescein dyes. Dev Biol 111:158-170.

Jaworski DM, Kelly GM, Hockfield S (1994) BEHAB, a new member of the proteoglycan tandem repeat family of hyaluronan binding proteins that is restricted to brain. J Cell Biol 125:495-509.

Kozak M (1984) Compilation and analysis of sequences upstream from the translational start site in eukaryotic mRNAs. Nucleic Acids Res 12:857-872.

Laemmli UK (1970) Cleavage of structural proteins during the assembly of the head of bacteriophage T4. Nature 227:680-685.

Lee MK, Rebhun LI, Frankfurter A (1990a) Posttranslational modification of class III b-tubulin. Proc Natl Acad Sci USA 87:7195-7199.

Lee MK, Tuttle JB, Rebhun LI, Cleveland DK, Frankfurter A (1990b) The expression and posttranslational modification of a neuron-specific beta tubulin isotype during chick embryogenesis. Cell Motil Cytoskel 17:118-132.

Lenoir D, Battenberg E, Kiel M, Bloom FE, Milner RJ (1986) The brain-specific gene 1B236 is expressed postnatally in the developing rat brain. J Neurosci 6:522-530.

Li W, Herman RK, Shaw JE (1992) Analysis of the Caenorhabditis elegans axonal guidance and outgrowth gene unc-33. Genetics 132: 675-689.

Martin KA, Grant SGN, Hockfield S (1992) The mas proto-oncogene is developmentally regulated in the rat central nervous system. Dev Brain Res 68:75-82.

McBurney MW, Reuhl KR, Ally AI, Masipuri S, Bell JC, Craig J (1988) Differentiation and maturation of embryonal carcinoma-derived neurons in cell culture. J Neurosci 8:1063-1073.

Minturn JE, Geschwind DH, Fryer HJ, Hockfield S (1995) Early postmitotic neurons transiently express TOAD-64, a neural specific protein. J Comp Neurol 355:369-379.

Pearson RB, Kemp BE (1991) Protein kinase phosphorylation site sequences and consensus specificity motifs: tabulations. Methods Enzymol 200:62-81.

Sambrook J, Fritsch EF, Maniatis T (1989) Molecular cloning: a laboratory manual. Cold Spring Harbor, NY: Cold Spring Harbor Laboratory Press.

Sanger F, Nicklen S, Coulson AR (1977) DNA sequencing with chainterminating inhibitors. Proc Natl Acad Sci USA 74:5463-5467.

Sano M, Katoh-Semba R, Kitajima S, Sato C (1990) Changes in levels of microtubule-associated proteins in relation to the outgrowth of neurites from PC12 cells, a forskolin- and nerve growth factor-responsive subline of PC12 pheochromocytoma cells. Brain Res 510: 269-276.

Sharma N, D'Arcangelo G, Kleinklaus A, Halegoua S, Trimmer JS (1993) Nerve growth factor regulates the abundance and distribution of $\mathrm{K}^{+}$channels in PC12 cells. J Cell Biol 123:1835-1843.

Siddiqui SS, Culotti JG (1991) Examination of neurons in wild type and mutants of Caenorhabditis elegans using antibodies to horseradish peroxidase. J Neurogenet 7:193-211.

Skene JHP, Willard M (1981) Axonally transported proteins associated with axon growth in the rabbit central and peripheral nervous systems. J Cell Biol 89:96-103.

Staines WA, Morassutti DJ, Reuhl KR, Ally AI, McBurney MW (1994) Neurons derived from P19 embryonal carcinomal cells have varied morphologies and neurotransmitters. Neuroscience 58:735-751.

Stein R, Orit S, Anderson DJ (1988) The induction of a neural-specific gene, SCG10, by nerve growth factor in PC12 cells is transcriptional, protein synthesis dependent, and glucocorticoid inhibitable. Dev Biol $127: 316-325$

Tischler AS (1975) Nerve growth factor-induced process formation by cultured rat pheochromocytoma cells. Nature 258:341-342.

Towbin H, Staehelin T, Gordon J (1979) Electrophoretic transfer of proteins from polyacrylamide gels to nitrocellulose sheets: procedure and some applications. Proc Natl Acad Sci USA 76:4350-4354.

Vetter J, Betz H (1989) Expression of synaptophysin in the pheochromocytoma cell line PC12. Exp Cell Res 184:360-366. 